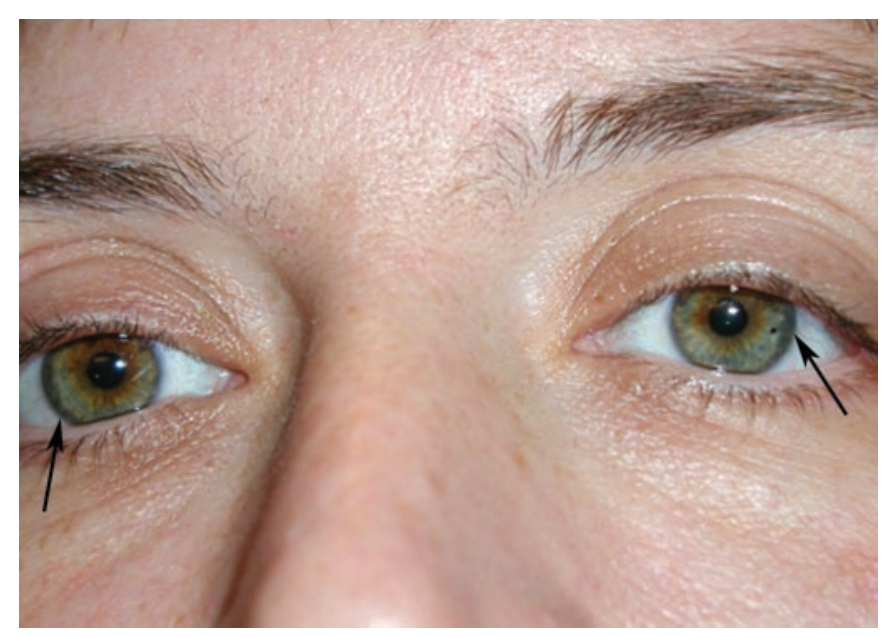

Figure A. External ophthalmologic examination revealed the presence of bilateral Kayser-Fleischer rings, most prominently seen laterally (arrows).

\section{The “double panda sign" in Wilson's disease}

Dina A. Jacobs, MD; Clyde E. Markowitz, MD;

David S. Liebeskind, MD; and Steven L. Galetta, MD

A 36-year-old woman presented with severe dysarthria, axial and appendicular tremor, and ataxia. Symptoms began with the tremor 2 years prior to presentation. Neurologic examination revealed the presence of Kayser-Fleischer rings (figure, A), severe dysarthria and dysphonia, akathisia, truncal and appendicular tremor, left hemiparesis, and dystonia. Serum ceruloplasmin was markedly decreased at $10 \mathrm{mg} / \mathrm{dL}$ (normal 18 to $55 \mathrm{mg} / \mathrm{dL}$ ). An MRI revealed diffuse white matter abnormalities with bilateral symmetric involvement of the midbrain, pons, inferior cerebellum, thalami, internal capsules, external capsules, and splenium of the corpus callosum. The MRI abnormalities in the midbrain (figure, B) reveal the "face of the giant panda" sign that is characteristic of Wilson's disease.$^{1}$ In addition, a second miniature "panda face" can be seen in the high signal abnormality in the pons (figure, C). The midbrain "panda sign" on T2-weighted MRI has been previously described as preservation of normal signal intensity in the red nuclei and lateral portion of the pars reticulata of the substantia nigra, high signal in the tegmentum, and hypointensity of the superior colliculus. ${ }^{1}$ The "face of the miniature panda" is seen within the pontine tegmentum. It is delineated by the relative hypointensity of the medial longitudinal fasciculi and central tegmental tracts ("eyes of the panda") in contrast with the hyperintensity of the aqueduct opening into the fourth ventricle ("nose and mouth of the panda") bounded inferiorly by the superior medullary velum (see figure, C). The superior cerebellar peduncles form the panda's "cheeks."

From the Department of Neurology, University of Pennsylvania School of Medicine, Philadelphia.

Received February 26, 2003. Accepted in final form June 10, 2003.

Address correspondence and reprint requests to Dr. D.A. Jacobs, Department of Neurology, 3 West Gates, 3400 Spruce St., Philadelphia, PA 19104; e-mail: daj37@mail.med.upenn.edu

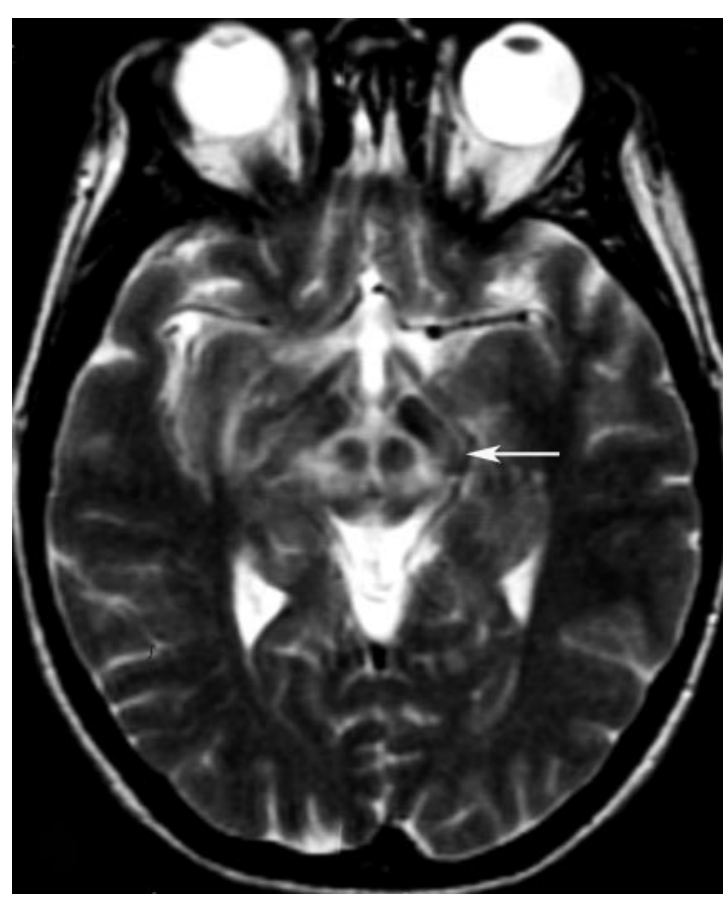

Figure B. T2-weighted axial MRI demonstrates the "face of the giant panda" in the midbrain (arrow).

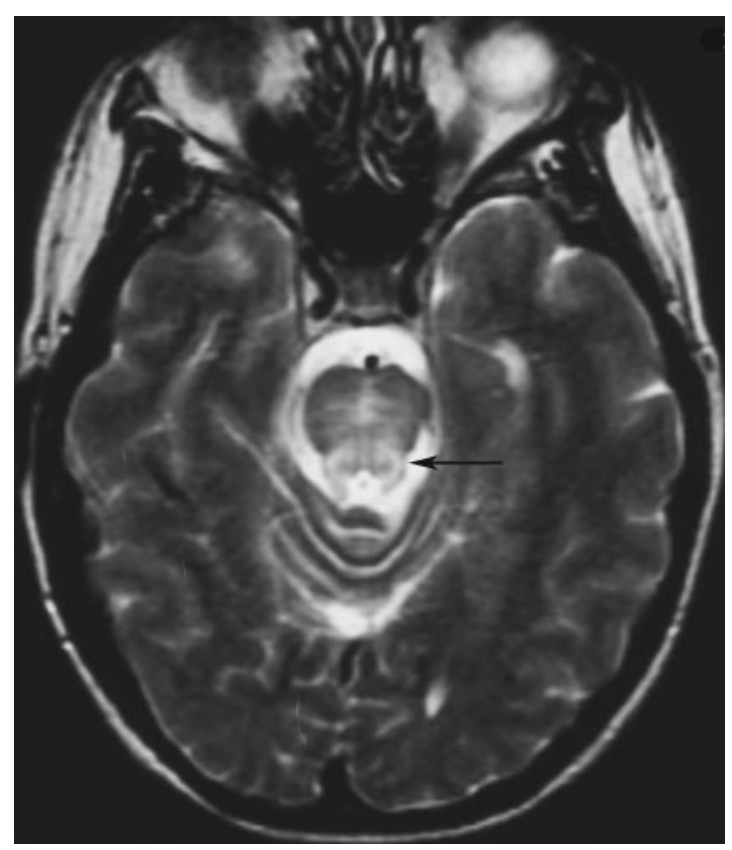

Figure C. T2-weighted axial MRI reveals the "face of the miniature panda" in the pontine tegmentum (arrow).

1. Hitoshi S, Iwata M, Yoshikawa K. Mid-brain pathology of Wilson's disease: MRI analysis of three cases. J Neurol Neurosurg Psychiatry 1991; $54: 624-626$ 


\title{
Neurology
}

\author{
The "double panda sign" in Wilson's disease \\ Dina A. Jacobs, Clyde E. Markowitz, David S. Liebeskind, et al. \\ Neurology 2003;61;969 \\ DOI 10.1212/01.WNL.0000085871.98174.4E
}

This information is current as of October 13, 2003

\section{Updated Information \& Services}

References

Citations

Subspecialty Collections

Permissions \& Licensing

Reprints including high resolution figures, can be found at: http://n.neurology.org/content/61/7/969.full

This article cites 1 articles, 1 of which you can access for free at: http://n.neurology.org/content/61/7/969.full\#ref-list-1

This article has been cited by 2 HighWire-hosted articles: http://n.neurology.org/content/61/7/969.full\#\#otherarticles

This article, along with others on similar topics, appears in the following collection(s):

All Movement Disorders

http://n.neurology.org/cgi/collection/all_movement_disorders

Metabolic disease (inherited)

http://n.neurology.org/cgi/collection/metabolic_disease_inherited MRI

http://n.neurology.org/cgi/collection/mri

Information about reproducing this article in parts (figures,tables) or in its entirety can be found online at:

http://www.neurology.org/about/about_the_journal\#permissions

Information about ordering reprints can be found online: http://n.neurology.org/subscribers/advertise

Neurology ${ }^{\circledR}$ is the official journal of the American Academy of Neurology. Published continuously since 1951, it is now a weekly with 48 issues per year. Copyright . All rights reserved. Print ISSN: 0028-3878. Online ISSN: 1526-632X.

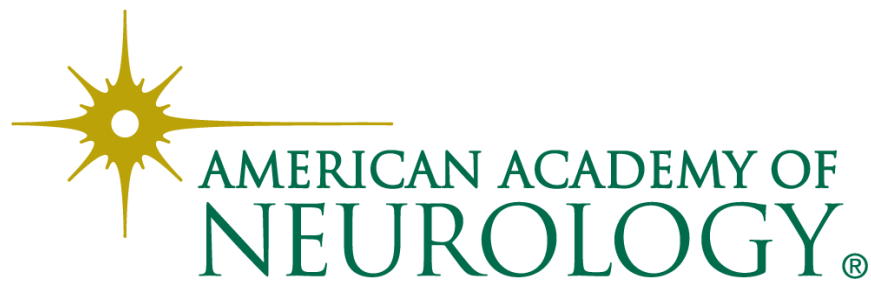

